(1)

George Fox

UNIVERSITY

\section{Digital Commons @ George Fox University}

2015

Exploring Culture-Specific Learning Styles in Accounting

Education

Seth E. Sikkema

Joshua Sauerwein

Follow this and additional works at: https://digitalcommons.georgefox.edu/gfsb

Part of the Business Commons 


\title{
Exploring culture-specific learning styles in accounting education
}

\author{
Seth E. Sikkema and Joshua A. Sauerwein \\ Department of Accounting, College of Business, George Fox University, \\ Newberg, Oregon, USA
}

\begin{abstract}
Purpose - The purpose of this paper is to review whether culture affects accounting students' learning processes to identify practical guidance for accounting educators facing a culturally diverse classroom. In spite of a significant literature thread in accounting education on student learning, relatively, little emphasis has been placed on culture-specific learning differences. The literature gap is particularly acute with respect to practical culture-specific guidance for accounting educators. This paper is organized along three primary inquiries into the role of culture in accounting education: first, do we know if culture impacts learning? Second, how much do we know about culture-specific learning styles in the accounting field? Third, what implications do culture-specific learning styles carry for accounting educators?

Design/methodology/approach - Initially, the author surveys culture-specific learning styles literature, after which a more in-depth analysis of accounting-specific literature is conducted. The author then provides a synthesis of the literature followed by a discussion of the implications for accounting educators.

Findings - Culture-specific learning styles carry several implications for educators such as problems associated with overloading short-term memory, the importance of prior experience and the role of visual prompts and motivation among students and educators.

Research limitations/implications - It is an opportunity for accounting educators to explore practical teaching techniques that address differences in learning styles that result from culture.

Practical implications - Culture-specific learning styles carry several implications for educators. Problems with culture may ultimately be associated with overloading short-term memory. Likewise, prior experience is an important aspect of culture-specific learning and should be recognized by accounting educators. Last, not all motivation need be sourced from the student, and instructors may explore the role of visual prompts when teaching international students.

Originality/value - This paper highlights the importance of culture-specific learning styles research in accounting education and the need for accounting educators to carefully consider cultural implications, as international accounting education standards are pursued. The dearth of research into culture-specific learning styles in accounting education is addressed.
\end{abstract}

Keywords Business education, Culture, Accounting education, Learning styles

Paper type Literature review

\section{Introduction}

The complexities of globalization have impacted many areas of society, not the least of which is the accounting profession. In a world that continues to "flatten" under the pressure of technological improvements and information availability, calls for reform and increased access to efficient information constructs have developed at an 
unrelenting rate. One such call to action in the USA is the international pressure to reform and conform to a single, global, principles-based accounting system (Schipper, 2003). Despite being fraught with implementation difficulties, it seems likely that many firms will ultimately benefit from a global standardization of accounting principles (Hail et al., 2010).

Similar globalization pressures face higher education. Though institutions are encouraged to promote international business skills and education, many prescribe structure or content rather than address the deeper issues of learning and pedagogy (Bruner and Iannarelli, 2011; Duff and Mladenovic, 2014; Geringer and Pendergast, 2010; Munter and Reckers, 2009; Walker, 2009). Some institutions may even be antagonistic toward the globalization of accounting education (Watty et al., 2013). This is exacerbated by unprecedented changes in student mobility and global education platforms. For example, the Organisation for Economic Cooperation and Development (OECD) recently indicated that nearly 4 million students were enrolled outside their country of citizenship and that 52 per cent of these students were from the Asian countries, in descending order, of China, India and Korea (OECD, 2011).

In both cases, whether facing changes to standard-setting or increased student mobility, the accounting discipline must consider the importance of proper contextualization and encoding. Accounting, as an information medium, should be appropriately contextualized and encoded such that a consistent, comparable deliverable can be achieved across global settings (Demski et al., 2002). It seems clear that context, in these cases, often involves differences in culture, language and behavior between nations and/or ethnicities. Therefore, accounting educators should carefully consider any differences in context and any relationship between context and the proper encoding of information. More specifically, if accounting educators intend to meet the demands of a globalized accounting profession and higher education system, then the interaction of culture and learning must be appropriately considered and addressed. One key question is whether culture (context) affects accounting students' learning (encoding) processes. This question seems particularly relevant to accounting instructors given the recent emphasis in accounting education on high-quality teaching (Pathways, 2012), recruitment of diverse entrants into the profession (IAESB, 2013; Pathways, 2013) and global education standards (IAESB, 2013; McPeak et al., 2012). Despite the progress made by the Pathways Commission (2013) and the International Accounting Education Standards Board (2013), a significant implementation gap persists in accounting education, particularly as it relates to providing practical guidance when working with students from culturally diverse contexts.

The purpose of this paper is to explore whether culture affects accounting students' learning processes to identify practical guidance for accounting educators facing a culturally diverse classroom. This paper modifies Eaves' (2011) approach by restricting the role of learning and culture to accounting education, a domain which remains underdeveloped. This paper contributes to the literature by bridging the gap between theory and practice. As such, the remainder of the paper investigates the role of culture in accounting education, organized into the following three pedagogical issues: First, do we know if culture impacts learning? Second, how much do we know about culture-specific learning styles in the accounting field? Third, what implications do culture-specific learning styles carry for accounting educators? The first and second 
questions provide the contextual setting for the remainder of the paper which describes strategies accounting instructors might use in culturally diverse classroom settings.

\section{Literature review}

The following section reviews a survey of culture-specific learning style research and is organized into two parts. The first part addresses the question of whether there is evidence of culture affecting learning styles. The second part examines how much we know about culture-specific learning in accounting education.

\section{How culture impacts learning styles}

Due to the pronounced differences in culture, Asian and Western students are often the subjects of culture-specific learning style research. For example, Hutchinson and Gul (1997) studied final year Hong Kong students and found that culture mediates the effect of extroversion/introversion on student learning preferences. In another study, Dunn and Shome (2009) examined the ethicality of Chinese and Canadian business students, and demonstrated that culture affects individual-level actions but not corporate-level actions, a phenomenon known as cultural cross-vergence. The authors also demonstrated that social desirability bias, or the degree to which an individual's values match the individual's peers, differs as a function of culture. Hu et al. (2013) compared cultural values of Australian and Chinese accounting students and showed that student's cultural values may changes as a result of acculturation and education. The authors also highlighted a clear difference in accounting judgments that result from cultural differences. Other studies incorporated comparisons between broader international student groups. For example, Evans and Waring (2011) compared three distinct groups of students across cognitive styles and cultural variables and found that culture affected student feedback preferences. In addition, Sulkowski and Deakin (2009) showed that the application of Hofstede's $(1980,2001)$ cultural dimensions is helpful for identifying cultural differences of learners, but does not yield a prescriptive panacea for all instructor actions.

While these studies imply that culture does indeed impact learning styles, there is other research that contradicts this notion. For example, Wong (2004) developed a mixed methods project that assessed Asian students' perceptions of the major challenges faced while studying at a foreign university and noted that most were able to adapt quickly to new styles of teaching and learning. Wong's results contradict the notion of culture-specific learning styles and instead suggested that learning styles may be contextual. These contradictions are inherent in a field which is still in relative infancy, as aptly noted by Eaves (2011). The underdeveloped stage of learning styles research, combined with debates over the validity and legitimacy of the terms "culture" and "learning styles", makes it very difficult to determine a single culture-specific learning style construct. So, while evidence exists that culture impacts learning styles, it is often in disparate form making it difficult to identify any particular construct.

An example of the challenges faced by any given construct can be demonstrated by reviewing the surface-deep learning model. Biggs (1991) described surface learning as rote, sans critical and reflective thinking, with the student seeing the university as a means to an end. Deep learning is characterized by integrative learning, as students seek the underlying meaning of concepts, with the student being intrinsically motivated. A third category described by Biggs is the achieving approach, where students are 
motivated by high marks and can be linked to either surface or deep learning. Eaves (2011) documented various studies using the surface-deep model with Asian students and concluded that there seems to be some evidence for culture-specific learning differences. However, Eaves (2011, p. 681) also referred to the "Asian student paradox", a term coined by Kember (2009) that highlights the inconsistency in the literature in characterizing Asian students as primarily surface learners.

One example of inconsistency is a recent study of Chinese students which showed that the students were motivated toward an achieving approach when outcomes-based learning was used, and, interestingly, also documented switching between learning approaches (Pang et al., 2009). It is the switching of learning modes by students which contradicts some research findings concerning Asian students using the surface learning approach. This apparent contradiction is addressed more thoroughly by Kember (2009) and, especially as it relates to accounting students, by Cooper (2004). On the one hand, Western teachers seem flummoxed by Asian student study behaviors, yet research comparing Asian students internationally revealed that these students often achieve high marks. Eaves (2011) rightly observed that this paradox calls into question both the validity and conclusions of Asian student learning style research. Kember (2009) provided evidence, noting that learning style research has indicated that Asian student study habits can often be misinterpreted by Western teachers. Apparently, the key to understanding the paradox is that Asian students combine memorization with intent to understand, whereas Western students solely aim to memorize (Cooper, 2004; Eaves, 2011).

Overall, the literature supports the notion that culture-specific learning styles exist. However, it is interesting to note that culture-specific learning styles are not necessarily static. Marriott (2002) showed that differences in learning style preferences change over time in a study conducted during students' tenure at a university. Students appear to switch depending on context and motivation. Educators should be encouraged by the level of student adaptability. These findings also suggest that educators should carefully consider teaching and learning with a diverse student population. In particular, educators should take care to avoid prescriptive, rote treatments based on culture-specific learning styles, instead offering a rich set of opportunities to engage students in content.

\section{Accounting and culture-specific learning styles}

There have been several clarion calls for accounting education reforms over the past thirty years (Accounting Education Change Commission, 1990; Albrecht and Sack, 2000; Bedford et al., 1986). More recently, high-quality teaching has been re-emphasized again (IAESB, 2013; Pathways, 2012), as have calls for standardization of international accounting education (IAESB, 2013; McPeak et al., 2012). Some noted that practitioners continue to demand a greater variety of knowledge and skills (Albrecht and Sack, 2000), yet others disagreed about whether this should be the goal of accounting education (Bui and Porter, 2010) and even whether a single, generalized accounting curriculum could be developed across higher education (Johnson et al., 2008). These various perspectives highlight the many differences in educator, practitioner and regulator expectations when it comes to accounting education (Bui and Porter, 2010).

In spite of the many perspectives and calls for reform, a relatively underdeveloped area of research in accounting education is in culture-specific learning styles. This is 
particularly important considering the trends of international (i.e. non-domestic) students in higher education. Although the USA experienced a relative decrease in international students from 2000 to 2009, it still has the highest market share of international students (18 per cent) in the world. During the same period, the average annual growth rate of international students studying at international universities was 6.6 per cent $(\mathrm{OECD}, 2011)$. The continued globalization of businesses, markets and education, not to mention the rise of online learning platforms, raises the importance of research that examines the intersection of culture with teaching and learning. The following section summarizes a sampling of culture-specific teaching and learning research in accounting education which use either psychometric or non-psychometric research designs.

Much of the learning styles research in accounting uses Kolb's (1976) experiential learning model (ELM). The ELM breaks learning down into processes as opposed to outcomes and contains four discrete phases: concrete experience (CE), reflective observation (RO), abstract conceptualization (AC) and active experimentation (AE). In theory, different individuals will prefer different stages of the learning cycle as opposed to others which helps categorize individuals into four styles: accommodator (CE and $\mathrm{AE})$, diverger ( $\mathrm{CE}$ and $\mathrm{RO})$, assimilator $(\mathrm{RO}$ and $\mathrm{AC})$ and converger ( $\mathrm{AC}$ and $\mathrm{AE})$. The learning cycle can be entered at any given stage but must be completed in the sequence proposed by Kolb (1976). Mckee et al. (1992) investigated learning style preferences of Norwegian and US accounting students using Kolb's (1976) learning style model. The research showed that the dominate Kolb's (1976) learning style for Norwegian students was assimilator, while US students preferred the conveger style. The authors also discovered that learning style preferences are impacted by both student experience level and native language instruments. These results imply that differences in cultural context exist and that teaching toward a single learning style may be ineffective strategy, as the internationalization of accounting education continues to occur.

Auyeung and Sands (1996) explored the effect of cultural orientation on learning styles of Chinese, Taiwanese and Australian accounting students. Using Kolb's (1976) learning style model the authors found support for differences in learning styles among the three student groups depending on whether the students were in a more individualistic or collectivistic culture. Chinese and Taiwanese students were shown to be more abstract and reflective, while Australian students were more concrete and active. It is surprising to note, even with somewhat similar cultures, that Chinese and Taiwanese students' learning styles differed. As a result, Auyeung and Sands (1996) suggested that a single, universal learning style is unlikely to exist for a given field of study.

Marriott (2002) conducted longitudinal learning style research among undergraduate accounting students in the UK. Kolb's (1976) dimensions were used to detect differences in learning styles and whether learning styles changed over a student's tenure at university. Students most commonly preferred the Accomodator dimension, but changes in learning styles were detected over the course of a student's academic career. Learning styles were also analyzed across gender, nationality and institution. These results highlight the importance of developing teaching tactics which best assist student learning, particularly at different phases of a student's academic progress.

Cooper (2004) used a comparative study of Chinese and Australian accountancy students to better understand the “Asian student paradox.” Using Bigg's (1991) model of 
surface and deep learning approaches, the author showed that the learning approaches among Chinese and Australian student groups differed. Interestingly, Chinese students scored higher than Australian students for both surface and deep approaches. Cooper (2004) explained that surface learning is often mischaracterized as mechanical rote learning. These results suggest that surface learning, particularly memorization with a goal of understanding, can improve academic performance and help explain "the enigma of the Chinese learner" (Cooper, 2004, p. 306).

Adler et al. (2004) studied the effect of teacher-led versus student-led case studies on learning preferences. The authors contended that student learners are more balanced when engaging in all four stages of Kolb's (1976) learning cycle, yet found that exposure to case studies, by itself, did not lead to more balanced learning styles. However, Adler et al. (2004) performed pre-test and post-test analyses which indicated that student learning preferences shifted from Kolb's (1976) accomodator and diverger toward Assimilator. The authors implied that the correct use of case studies impacts student learning styles. Wynn-Williams et al. (2008) extended Adler et al.'s (2004) research by using pre/post-test design which incorporated multiple case studies over a longer treatment period than used in the first study. The 2008 study showed that higher levels of student involvement in cases resulted in more balanced learning styles. It should be noted that Duff et al. (2008) critiqued the theoretical framework and findings of both Adler et al. (2004) and Wynn-Williams et al. (2008). Adler et al. (2008) vigorously defended their work. Regardless, both sets of results, paired with Marriott (2002), support the notion that learning styles are dynamic and change over time.

Accounting researchers have also utilized Hofstede's (1980, 2001) cultural dimensions model in learning styles studies. Hofstede $(1980,2001)$ investigated national culture differences and identified four dimensions which help explain cultural variations. The first is power distance or the extent to which the less powerful people in a group accept and expect that power is distributed unequally. Second is uncertainty avoidance or a person's ability to deal with ambiguity. Next is individualism, as opposed to collectivism. Last is masculinity or the way that emotional roles are allocated among different genders. Each dimension represents a continuum. For example, two students may differ along the individualism dimension, where one prefers to study individually while another may prefer to study collectively. Later research revealed a fifth dimension, long-term versus short-term orientation (Hofstede and Bond, 1988). A recent study examined the preferred learning modes of international and domestic accounting students in an Australian university (Abeysekera, 2008). Using Hofstede's (1980, 2001) cultural dimensions, the author surveyed 296 students to determine preference for traditional lecture, interactive lecture or group case study-based lecture. Unexpectedly, the results indicated that international students did not prefer to avoid learning new material. International students also, surprisingly, preferred interactive and group case study lectures as compared to domestic students. Abeysekera (2008) rightly noted that these results contradicted some research findings and may be the result of other mediating factors, such as length of time spent in the foreign university and exposure to interactive learning. Regardless, the results imply that international students may be more adaptable than some Western research indicates and a finding that is consistent with Wong (2004).

Burch provided a unique case study of a first-semester master's level accounting course at an Australian university (2008). The author documented a general shift in 
student learning strategies during a five-year period ending in 2008. Among other observations, the author noted increased failure rates, higher levels of intra-student animosity, lower levels of preparation and growth of the international student population that ultimately put the domestic students in the minority. As a result, many of the international students are unable to demonstrate competency. According to Burch (2008), a key problem was international students' prior-learning strategies that were carried into the course. In addition, international students appeared to have disparate objectives as compared to domestic students. This seems to contradict other research findings (Abeysekera, 2008; Wong, 2004) demonstrating international student adaptability, though it might also suggest that adaptability is accelerated as international students spend more time acclimating at the host university.

Another study empirically investigated how cultural factors affect learning style preferences between Australian and Japanese accounting students (Sugahara and Boland, 2010). The authors used Kolb's (1976) learning style and Hofstede's cultural dimensions models to investigate learning style patterns and demonstrated a linkage between individualism and learning by doing/watching. In other words, the collectivist Japanese students preferred to learn by watching while the more individualistic Australian students preferred to learn by doing. Sugahara and Boland (2010) also showed that culture is not necessarily the primary explanatory factor in students' learning style preferences. These results suggest that cultural differences are important to consider but may not be an insurmountable issue for accounting educators.

Duff and Mladenovic (2014) studied a comprehensive set of variables utilizing each stage of the 3Ps model - see Duff and McKinstry (2007) for an excellent discussion of the 3Ps model. In short, the 3Ps model contains three distinct stages: presage (e.g. antecedents), process and product. The 3Ps model posits that the quality of student learning (product) is a function of a student's background (presage), expectations of learning (presage) and approaches to learning (process). Cluster analysis yielded three distinct levels of student expectations for learning. Not surprisingly, those with high expectations had the most positive views of learning accounting, while those low expectations perceived accounting as a subject to be feared. While culture was not an explicit aim of the study, Duff and Mladenovic (2014) built language and other presage variables into their cluster analysis. Interestingly, the highest proportion of students where English was a second language (ESL) fell into the low, or maladaptive, cluster. The results indicate that a holistic examination of 3Ps factors may be more beneficial than exploring a single variable, such as language, in isolation. The results from ESL students suggest that educators may need to spend more time supporting the development of positive learning expectations in students with cultural differences. Taken as a whole, the culture-specific learning styles research in accounting education appears to mirror the broader literature. Evidence exists that culture is an important variable in accounting education, but may be influenced by situational context, duration of study at a host university and language ability. Prior learning strategies may also influence students. However, there is also evidence that international students are highly adaptable to the learning environment and the effect of culture may diminish with time. Clearly though, there are many culture-specific learning style questions in accounting education which remain unanswered and which may help explain in part why contradictory results emerge. Regardless, accounting educators clearly need to consider how to promote effective and efficient learning by using a wide variety of 
learning activities, particularly if those activities can be tailored to fit students' cultural realities.

\section{Implications for research and practice}

This section of the paper provides a brief series of practical, culture-specific learning styles guidance for accounting educators using a framework proposed by Walstad et al. (1998), as well as the preceding review of extant literature. First, a series of recommendations for educators is developed, followed by a brief review of limitations and suggestions for future research.

\section{Implications for accounting educators}

There is still considerable debate over what "learning" actually means, and there remains no single generally accepted theory of learning. Most educators would agree that learning is dynamic, occurring in different ways, at different times, for different people. Even still, there seem to be four generally held propositions of the learning process that could aid accounting educators facing a globalized context:

(1) the limited capacity to process information;

(2) the importance of prior experience;

(3) the importance of motivation; and

(4) the dominance of visual over verbal (Walstad et al., 1998).

These four propositions may help frame the discussion of culture-specific learning styles and will be briefly discussed in turn below.

Cognitive load: a limited capacity to process information. The human mind contains a limited ability to process information, otherwise known as cognitive load. Cognitive load theory, in essence, is that learners have a very limited working memory capacity when dealing with new information, yet have essentially unlimited long-term memory architecture (Artino, 2008). Research has shown that an individual is able to handle about seven "chunks" of information in short-term memory at any given point in time (Walstad et al., 1998). Overloading short-term memory causes confusion, inefficiency and ultimately information loss. The implications for accounting educators are clear: covering too much new content will result in deteriorated learning. Educators should resist the temptation to "cover the field". This is especially important when considering international students, who may not be able to handle as many "chunks" in short-term memory as a result of simultaneously processing content, language and other cultural artifacts. One good practice for accounting educators would be to carefully crafting four to seven informational "chunks" of learning for each lesson session, regardless of student diversity. As new information is quickly lost from working memory, immediate rehearsal is also helpful. For example, a 5 to 10 minute mini-case could be used immediately after introducing a new accounting concept. Consideration should also be given to the importance of memorization. When structured in a manner that focuses on memorization for understanding, this technique can be highly effective across cultures. For example, students could be encouraged to memorize the Association of Certified Fraud Examiners (ACFE) Code of Professional Ethics (2015), but with the goal of applying the Code to a variety of ethical scenarios. The action of probing and applying 
the memorized Code, rather than simple recall and recitation, encourages deep and more balanced learning.

Importance of prior experience. There is general agreement that long-term memory is organized into a hierarchy where prior experience helps frame new learning. Great differences in prior experience between instructor and student can lead to confusion, causing the student to view new content as meaningless (Walstad et al., 1998). It is therefore important for accounting educators consider prior experience of students and, in some cases, take extra time to bring the student up to a common level of understanding. The concept of prior experience is particularly relevant when teaching international accounting students, as several research studies have documented the impact of prior experience on learning styles, especially in the early stage of a student's tenure at a foreign university. A possible approach to minimize the effect of prior experience on international students would be to frame homework or other in class examples within a familiar cultural context. For example, many accounting examples include business scenarios that could be easily tailored to a Chinese context. Consideration should also be given to the gradual shift in learning preferences over a student's academic tenure. For example, as a student progresses through an accounting program, it may be helpful to slowly expand business scenarios that include less familiar cultural contexts. The progression of cultural contexts may help avoid the expertise reversal effect (Artino, 2008) where highly effective teaching tactics for novices wear off and even become detrimental as the leaner becomes more experienced.

Importance of motivation. Intrinsic student motivation can be varied by information content and certainly is not static, though it may be shaped by external forces. Regardless, there is ample evidence that instructors can impact a student's extrinsic motivation by appealing to the affective domain (Walstad et al., 1998). In other words, enthusiastic instructors can positively influence student learning by creating challenging, but attainable course content. The motivation dimension seems particularly important to consider in learning style preference research. In an international context, where international students' motivations are at times unclear, it can be helpful for the accounting educator to value the students' feelings and emotions, show enthusiasm for the content and a general sense of care for student learning. Accounting educators can also foster higher international student engagement through careful construction of shared learning experiences. Shared learning experiences might range from blended student-led case studies to individualized international student mentors. Recent research has also suggested that proper support services are critical for international student engagement. Accounting program designers should consider whether providing support networks where international students can collectively share their educational experiences and needs. At a minimum, accounting educators should help foster positive learning expectations for international students.

Dominance of visual over verbal. Researchers have shown that a dual trace system exists for processing visual and verbal information (Walstad et al., 1998). Visual and verbal information are coded differently and, when combined together in a learning environment, persist longer in memory than verbal only constructs. This may help explain why the process of memorization by Asian students includes a component of understanding (Eaves, 2011). Asian students who memorize would be actively engaging in both visual (examining a foreign language or symbol) and verbal (discussing its underlying meaning). Accounting educators should further consider how the use of 
visual prompts in accounting education would improve how information "sticks" in the learner's mind. Visual aids could be particularly important for international students when combined with prior experience. For example, when considering the cost of constructing a building, an instructor might help a Chinese student frame the historical cost concept by using a picture of a traditional Chinese building and discussing the cost components used during construction.

In sum, there are many opportunities to integrate what we know about culturespecific learning styles with generally accepted learning propositions. In doing so, accounting instructors should avoid stereotyping and should seek institutional support and training (Eaves, 2011). An integrative approach that considers students' limited ability to process information and prior experience, which promotes challenging but attainable learning goals, and incorporates the use of visual learning elements, should foster deep learning by both domestic and international students.

\section{Limitations and future research}

The general lack of abundant research in culture-specific learning styles, particularly as it relates to accounting education, is problematic. Also, due to the dynamic nature of culture-specific learning styles, and learning theory in general, educators should exercise caution when research results, as findings represent generalizations and not absolute patterns. Furthermore, much of the research on culture-specific learning styles originates from Western cultures (USA, Australia and UK) and may misinterpret or misrepresent non-Western learning (Eaves, 2011). Other factors, such as support services, not currently addressed in learning styles literature may also impact international student performance. For example, there is evidence suggesting that support services for international students play an instrumental role in their educational development. Roberts and Dunworth (2012) suggest that insufficient support services may prevent international students from fully functioning at university. Likewise, Padlee and Reimers (2015) showed that academic services have a direct impact on international student satisfaction. Finally, some of the contradictory research results indicate a lack of precision inherent in early stages of researching a domain; care should be taken before labeling certain culture-specific learning styles as deficient.

Very few studies attempt the holistic exploration of learning. Duff and Mladenovic (2014) rightly identify the need to investigate learning systems in aggregate, as many learning components often work in conjunction with each other. Future research focused on a holistic systems approach could provide greater clarity into messy, often contradictory domain of culture-specific learning. In addition, a significant proportion of learning research is dominated by large educational institutions and their students. Future studies which examine smaller samples in higher education settings may provide valuable insights. Likewise, there is a lack of qualitative research into culture-specific learning, especially as it relates to the quality of learning outcomes. Future research is needed which qualitatively addresses how to achieve "good performance" (as opposed to good test scores) for those students from culturally diverse backgrounds.

\section{Conclusion}

There are many forces facing the academic and professional fields of accounting, chief among them the continued internationalization of corporate entities, educational 
systems and people groups. Culture-specific learning styles are important elements to better understand how cultural factors intersect with accounting education and should be considered seriously. This paper addressed the question of whether context (culture) affects accounting students' encoding (learning) processes. This was examined along three primary inquiries into the role of culture in accounting education: First, do we know if culture impacts learning? Second, how much do we know about culture-specific learning styles in the accounting field? Third, what implications do culture-specific learning styles carry for accounting educators?

A survey of the culture-specific learning styles literature shows that culture does indeed impact learning, but this research is often messy with contradictions and lacks an overarching, generally accepted framework. This is due at least in part to the dynamism of learning and the human mind. More specific research into the role of culture-specific learning styles in accounting education reveals a field of research that is underdeveloped with few accounting specific findings. That is not to say that these literature streams were unfruitful; indeed, several interesting threads emerged. One is that international students have more learning adaptability than previously believed. A second is that culture is important, but not too difficult to overcome in the classroom.

Finally, culture-specific learning styles carry several implications for educators. Careful consideration should be given to the constraints present in the human mind. Problems with culture may ultimately be associated with overloading short-term memory. Likewise, prior experience is an important aspect culture-specific learning and should be recognized by accounting educators. Last, not all motivation need be sourced from the student, and instructors may explore the role of visual prompts when teaching international students. In sum, culture-specific learning seems to be more about integrative learning than a prescriptive panacea that can be uniformly installed to improve student learning.

\section{References}

Abeysekera, I. (2008), "Preferred learning methods: a comparison between international and domestic accounting students", Accounting Education, Vol. 17 No. 2, pp. 187-198. doi: 10.1080/09639280701220236.

Accounting Education Change Commission. (1990), "Objectives of education for accountants: position statement number one", Issues in Accounting Education, Vol. 5 No. 2, p. 307, available at: http://aaahq.org/AECC/pdf/position/pos1.pdf (accessed 27 August 2012).

Adler, R.W., Whiting, R.H. and Wynn-Williams, K. (2004), "Student-led and teacher-led case presentations: empirical evidence about learning styles in an accounting course", Accounting Education, Vol. 13, pp. 213-229. doi: 10.1080/09639280410001676620.

Adler, R.W., Whiting, R.H. and Wynn-Williams, K. (2008), "On approaches to learning versus learning styles: a reply to Duff et al.'s comment", Accounting Education, Vol. 17, pp. 145-149. doi: 10.1080/09639280701788687.

Albrecht, W.S. and Sack, R.J. (2000), "Accounting education: charting the course through a perilous future", Accounting Education Series No. 16. American Accounting Association, Sarasota, FL, available at: http://aaahq.org/pubs/AESv16/toc.htm (accessed 27 August 2012).

Artino, A.R. (2008), "Cognitive load theory and the role of learner experience: an abbreviated review for educational practitioners", AACE Journal, Vol. 16 No. 4, pp. 425-439. 
Association of Certified Fraud Examiners (ACFE) (2015), "Code of professional ethics code-of-ethics", available at: www.acfe.com/uploadedFiles/ACFE_Website/Content/ documents/Code-Of-Ethics.pdf (accessed 18 August 2015).

Auyeung, P. and Sands, J. (1996), "A cross cultural study of the learning style of accounting students”, Accounting \& Finance, Vol. 36 No. 2, p. 261. doi: 10.1111/j.1467-629X. 1996.tb00310.x.

Bedford, N., Bartholomew, E.E., Bowsher, C.A., Brown, A.L., Davidson, S., Horngren, C.T., Knortz, H.C., Mendel Piser, M., Shenkir, W.G., Simmons, J.K., Summers, E.L. and Wheeler, J.T. (1986), SPECIAL REPORT Future Accounting Education: Preparing for the Expanding Profession, American Accounting Association, No. 1, p. 168, available at: http:// aaahq.org/AECC/future/cover.htm (accessed 27 August 2012).

Biggs, J.B. (1991), “Approaches to learning in secondary and tertiary students in Hong Kong: some comparative studies”, Educational Research Journal, Vol. 6 No. 1, pp. 27-39.

Bruner, R.F. and Iannarelli, J. (2011), "Globalization of management education”, Journal of Teaching in International Business, Vol. 22 No. 4, pp. 232-242. doi: 10.1080/ 08975930.2011.653908.

Bui, B. and Porter, B. (2010), "The expectation-performance gap in accounting education: an exploratory study", Accounting Education, Vol. 19 Nos 1/2, pp. 23-50. doi: $10.1080 / 09639280902875556$.

Burch, T. (2008), "Teaching and learning accounting with overseas students", People and Place, Vol. 16 No. 1, pp. 12-20. (available at: http://dro.deakin.edu.au/eserv/DU:30017774/burchteachingandlearningaccounting-2008.pdf (accessed 27 August 2012).

Cooper, B. (2004), “The enigma of the Chinese learner”, Accounting Education, Vol. 13, pp. 289-310. doi: 10.1080/0963928042000273780.

Demski, J.S., Fellingham, J.C., Ijiri, Y., Sunder, S., Glover, J.C. and Jinghong, P. (2002), "Some thoughts on the intellectual foundations of accounting", Accounting Horizons, Vol. 16 No. 2 , pp. 157-168, available at: http://dx.doi.org/10.2139/ssrn.305904 (accessed 27 August 2012).

Duff, A., Dobie, A. and Guo, X. (2008), “The influence of business case studies and learning styles in an accounting course: a comment", Accounting Education, Vol. 17, pp. 129-144. doi: $10.1080 / 09639280701788729$.

Duff, A. and McKinstry, S. (2007), "Students' approaches to learning”, Issues in Accounting Education, Vol. 22, pp. 183-214. doi: 10.2308/iace.2007.22.2.183.

Duff, A. and Mladenovic, R. (2014), “Antecedents and consequences of accounting students' approaches to learning: a cluster analytic approach”, The British Accounting Review. doi: 10.1016/j.bar.2014.06.003, (accessed 21 June 2014).

Dunn, P. and Shome, A. (2009), "Cultural crossvergence and social desirability bias: ethical evaluations by Chinese and Canadian business students", Journal of Business Ethics, Vol. 85 No. 4, pp. 527-543. doi: 10.1007/s10551-008-9787-z.

Eaves, M. (2011), "The relevance of learning styles for international pedagogy in higher education", Teachers and Teaching, Vol. 17 No. 6, pp. 677-691. doi: 10.1080/ 13540602.2011.625143.

Evans, C. and Waring, M. (2011), "Exploring students' perceptions of feedback in relation to cognitive styles and culture", Research Papers in Education, Vol. 26 No. 2, pp. 171-190. doi: 10.1080/02671522.2011.561976.

Geringer, J.M. and Pendergast, W.R. (2010), "CEO views on the value of international business skills and education”, The International Journal of Management and Business, Vol. 1 No. 1, 
pp. 12-29, available at: www.iamb.net/IJMB/journal/IJMB_Vol_1_1.pdf\#page=12 (accessed 27 August 2012).

Hail, L., Leuz, C. and Wysocki, P. (2010), "Global accounting convergence and the potential adoption of IFRS by the US (Part I): conceptual underpinnings and economic analysis", Accounting Horizons, Vol. 24 No. 3, pp. 355-394. doi: 10.2308/acch.2010.24.3.355.

Hofstede, G. (1980), Culture's Consequences: International Differences in Work-related Values, Sage, Beverly Hills, CA.

Hofstede, G. (2001), Culture's Consequences: Comparing Values, Behaviors, Institutions, and Organizations Across Nations, 2nd ed., Sage, Thousand Oaks, CA.

Hofstede, G. and Bond, M.H. (1988), "The confucius connection: from cultural roots to economic growth”, Organizational Dynamics, Vol. 16 No. 4, pp. 4-21.

Hu, C., Chand, P. and Evans, E. (2013), "The effect of national culture, acculturation, and education on accounting judgments: a comparative study of Australian and Chinese culture", Journal of International Accounting Research, Vol. 12, pp. 51-77. doi: 10.2308/jiar-50507.

Hutchinson, M. and Gul, F.A. (1997), "The interactive effects of extroversion/introversion traits and collectivism/individualism cultural beliefs on student group learning preferences", Journal of Accounting Education, Vol. 15 No. 1, pp. 95-107. doi: 10.1016/S07485751(96)00046-2.

International Accounting Education Standards Board (IAESB) (2013), International Education Standard 1 (revised): Entry Requirements to Professional Accounting Education Programs, available at: www.ifac.org

Johnson, S., Schmidt, B., Teeter, S. and Henage, J. (2008), "Using the albrecht and sack study to guide curriculum decisions", Advances in Accounting Education, No. 9, pp. 251-266. doi: 10.1016/S1085-4622(08)09012-3.

Kember, D. (2009), "International students from Asia”, The Routledge International Handbook of Higher Education, Routledge, NY, pp. 47-60.

Kolb, D.A. (1976), Learning Style Inventory: Technical Manual, McBer and Company, Boston, MA.

Mckee, T.E., Mock, T.J. and Ruud, T.F. (1992), "A comparison of Norwegian and United States accounting students' learning style preferences”, Accounting Education, Vol. 1 No. 4, p. 321. doi: 10.1080/09639289200000049.

McPeak, D., Pincus, K.V. and Sundem, G.L. (2012), "The international accounting education standards board: influencing global accounting education", Issues in Accounting Education, Vol. 27, pp. 743-750. doi: 10.2308/iace-50121.

Marriott, P. (2002), “A longitudinal study of undergraduate accounting students' learning style preferences at two UK universities”, Accounting Education, Vol. 11, pp. 43-62. doi: 10.1080/ 09639280210153263.

Munter, P. and Reckers, P.M.J. (2009). "IFRS and collegiate accounting curricula in the United States: 2008. A survey of the current state of education conducted by KPMG and the education committee of the American accounting association", Issues in Accounting Education, Vol. 24 No. 2, pp. 131-139, available at: Business Source Complete, Ipswich, MA (accessed 27 August 2012).

OECD (2011), Education at a Glance 2011: OECD Indicators, OECD Publishing, Paris, Published under the authority of Angel Gurria, OECD Secretary-General, available at: http://dx.doi. org/10.1787/eag-2011-en (accessed 27 August 2012).

Padlee, S.F. and Reimers, V. (2015), "International student satisfaction with, and behavioural intentions towards, universities in Victoria", Journal of Marketing for Higher Education, Vol. 25, pp. 70-84. doi: 10.1080/08841241.2015.1042098. 
Pang, M., Ho, T.M. and Man, R. (2009), "Learning approaches and outcome-based teaching and learning: a case study in Hong Kong, China”, Journal of Teaching in International Business, Vol. 20 No. 2, pp. 106-122. doi: 10.1080/08975930902827825.

Pathways Commission on Accounting Higher Education (Pathways) (2012), "Pathways to a profession: charting a national strategy for the next generation of accountants", Sponsored by the American Accounting Association (AAA) and the American Institute of Certified Public Accountants (AICPA), available at: http://commons.aaahq.org/files/0b14318188/ Pathways_Commission_Final_Report_Complete.pdf (accessed 27 August 2012).

Pathways Commission on Accounting Higher Education (Pathways) (2013), "Implementing recommendations for the future of accounting education: the first year update", available at: http://commons.aaahq.org/posts/6153324d1b (accessed 13 August 2015).

Roberts, P. and Dunworth, K. (2012), "Staff and student perceptions of support services for international students in higher education: a case study", Journal of Higher Education Policy \& Management, Vol. 34, pp. 517-528. doi: 10.1080/1360080X.2012.716000.

Schipper, K. (2003), "Principles-based accounting standards", Accounting Horizons, Vol. 17 No. 1, pp. 61-72. Available at: Business Source Complete, Ipswich, MA (accessed 27 August 2012).

Sugahara, S. and Boland, G. (2010), "The role of cultural factors in the learning style preferences of accounting students: a comparative study between Japan and Australia", Accounting Education, Vol. 19 No. 3, pp. 235-255. doi: 10.1080/09639280903208518.

Sulkowski, N.B. and Deakin, M.K. (2009), "Does understanding culture help enhance students' learning experience?”, International Journal of Contemporary Hospitality Management, Vol. 21 No. 2, pp. 154-166. doi: 10.1108/09596110910935651.

Walker, J. (2009), "Language and culture requirements in international business majors at AACSB-accredited business schools", Journal of Teaching in International Business, Vol. 20 No. 4, pp. 293-311. doi: 10.1080/08975930903405050.

Walstad, W.B., Saunders, P. and Conrad, C.A. (1998), Teaching Undergraduate Economics: A Handbook for Instructors, Irwin McGraw Hill, Boston, available at: www.lavoisier.fr/livre/ notice.asp?id=OOLW36AO3KXOWE (accessed 27 August 2012).

Watty, K., Sugahara, S., Abayadeera, N. and Perera, L. (2013), "Developing a global model of accounting education and examining IES compliance in Australia, Japan, and Sri Lanka”, Accounting Education, Vol. 22, pp. 502-506. doi: 10.1080/09639284.2013.824199.

Wong, J.K. (2004), "Are the learning styles of Asian international students culturally or contextually based”, International Education Journal, Vol. 4 No. 4, pp. 154-166, available at: http://courses.essex.ac.uk/ia/ia409/selection_of_readings/Wong_Asian_Student_ Learning_Styles.pdf (accessed 27 August 2012).

Wynn-Williams, K., Whiting, R.H. and Adler, R.W. (2008), “The influence of business case studies on learning styles: an empirical investigation”, Accounting Education, Vol. 17, pp. 113-128. doi: 10.1080/09639280601026030.

\section{Corresponding author}

Seth E. Sikkema can be contacted at: ssikkema@georgefox.edu 